УДК: 574

\title{
КІРЛІАНОГРАФІЯ СТРУКТУРНО-ЕНЕРГЕТИЧНИХ ВЛАСТИВОСТЕЙ ВОДИ ЯК ІНФОРМАЦІЙНОЇ СИСТЕМИ В ОРГАНІЗМІ ЛЮДИНИ
}

\author{
М. В. Курик, Л. А. Пісоцька, В. М. Лапицький \\ Український Інститут Екології людини \\ ДВНЗ «Національний гірничий університет» ${ }^{1}$
}

\begin{abstract}
Стаття присвячена вивченню енергетики і структури води. Використовували метод класичної кірліанографії. Краплю води розташовували на рентгенівській плівці. Звертали увагу на ширину корони світіння, її інтенсивність, малюнок стримерів, зображення на внутрішньому крузі корони випромінювання. Досліджували воду з різними властивостями для визначення ознак, які можуть бути використані в оцінці стану енергетики води, її біологічної активності.
\end{abstract}

Ключові слова: класична кірліанографрія, вода.

\section{КИРЛИАНОГРАФИЯ СТРУКТУРНО-ЭНЕРГЕТИЧЕСКИХ СВОЙСТВ ВОДЫ КАК ИНФОРМАЦИОННОЙ СИСТМЕЫ В ОРГАНИЗМЕ ЧЕЛОВЕКА}

\author{
М. В. Курик, Л. А. Пісоцька, В. М. Лапицький ${ }^{1}$ \\ Украинский \\ Институт \\ Екологии \\ человека \\ ГВУЗ «Национальный горный университет» ${ }^{1}$
}

\begin{abstract}
Статья посвящена исследованию возможностей применения метода классической кирлианографии для определения энергетики и структуры воды. Сравнивались изображения кирлиановского свечения заведомо разной по свойствам и действию на организм воды. Исследовалась природная, «святая» вода в сравнении с водопроводной, сточной. Выявлены признаки, отличающие их, которые могут быть использованы как критерии биоэнергетических свойств воды.
\end{abstract}

Ключевые слова: классическая кирлианография, вода.

\section{KIRLIANPHOTOGRAPHY OF STRUCTURALLY-ENERGETIC PROPERTIES OF WATER AS AN INFORMATIONAL SYSTEM IN THE ORGANISM OF A MAN}

\author{
M. V. Kuryk, L. A. Pisotska, V. M. Lapytskyi ${ }^{1}$ \\ Ukrainian Institute of ecology of a man \\ ${ }^{1}$ SHEI «National Mining University»
}

\begin{abstract}
The work purpose was the analysis of the image of Kirlian glow of water using classical kirlianphotography at X-ray film from the standpoint of available today scientific concepts of the physical nature of water. This method allows to evaluate natural properties of water by the structure of the outer corona emission and properties of a drop of water on the film. There have been identified signs that reflected the energetic activity, structure of the finer outer and inner fields and fractality of water.
\end{abstract}

Key words: classical kirlianphotography, water.

Вступ. 3 літератури відомо про біологічні властивості води у живій істоті. Зокрема, вона є структурним компонентом біологічно активних речовин. Завдяки їй здійснюються ферментативні, імунні реакції, в яких взаємодія речовин проходить на надмолекулярному рівні [5].

Існує думка, що молекулярні взаємодії в клітинах і взаємодії клітин між собою здійснюються завдяки не стільки прямим контактам «твердих» молекул одна $з$ одною, скільки впливу однієї на одну оболонок води, які оточують ті чи інші молекули, або мікровихорів внаслідок тих чи інших процесів [1].

Встановлено, що природна вода має власне випромінювання [7]. В полі високої напруги воно підсилюється і візуалізується на рентгенівській плівці, фотоматеріалі, що відомо, як ефект Кірліан [4]. Тому 
використання цього методу доцільне для оцінки структурно-енергетичного стану води.

Метою дослідження було порівняти різну за структурно-енергетичними властивостями воду для встановлення ії кірліанографічних ознак, що має практичне значення в біології і медицині.

Матеріал і методи дослідження. Для проведення кірліанографії води використовували дослідницький прилад «РЕК 1», розроблений УкрНДІ технологій машинобудівництва і ДВНЗ «Національний гірничий університет» (м. Дніпропетровськ) [10]. Використовували рентгенівську плівку та стандартні методи іiі проявлення. Досліджували різні зразки води і порівнювали їі фізичні параметри.

\section{Отримані результати та їх обговорення.}

Радіальний напрямок розташування каналів іонізації молекул в короні випромінювання досліджуваних об'єктів, певно, зв'язаний не тільки з силовими лініями електромагнітного поля землі, але і з векторним (мітотичним або тонким) полем космічного походження, яке, за даними досліджень [9], властиве всім об'єктам 3 матричною структурою, зокрема воді. 3 цього, особливості малюнку стримерів корони світіння зв'язані з особливостями структури зразка води. На рис. 1 наведено приклади кірліан-світіння води, різної за структурою.

За даними досліджень Б. М. Стефанюка встановлено, що рідинна вода - це впорядкована триступе-

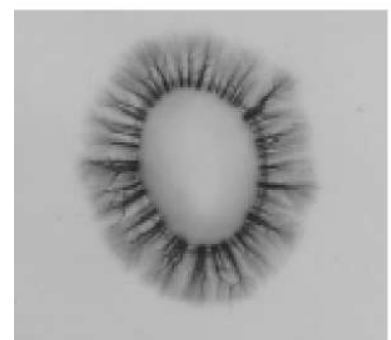

Тала вода

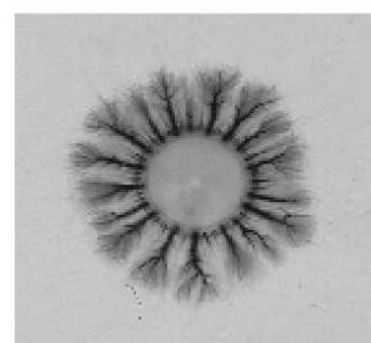

3 джерела Криму

нева структура 3 чітко виявленими властивостями на кожному ступені. Найважливішу роль у цій ієрархії відіграє перший ступінь - молекулярний ансамбль (МА), який визначає інтегральні характеристики води. МА розглядається як нанокристал, побудований iз пластин шестигранних сот, що мають стійку «хвилясту» (гофровану) будову. Деякі пластини різної величини з'єднуються між собою торцевими вільними водневими зв'язками, утворюючи при цьому сотові канали. Між пластинами, які утворюють ансамбль, $\epsilon$ центр симетрії, розташований на осі сотового каналу [11].

Звідси, структура стримерів зв'язана зі станом сотових каналів води. Можна припустити, що при руйнуванні МА змінюються або зникають і сотові канали. Повна або часткова відсутність випромінювання в короні світіння, зміни в симетрії іiі зображення віддзеркалюють ці негативні процеси в структурі води, що в полі високої напруги посилюються (рис. 2).

Вільні водневі зв'язки в МА води безпосередньо визначають активність іï іонізації, інтенсивність кірліанівського світіння, хімічну реактивність.

Прикладами зв'язку між інтенсивністю світіння розчину речовини у воді $і$ 1іi біологічними властивостями може бути різниця в кірліан-світінні розчинів право- і лівообертального ізомерів амінокислоти Lта D-лейцину відповідно. Згідно з [12], в склад при-

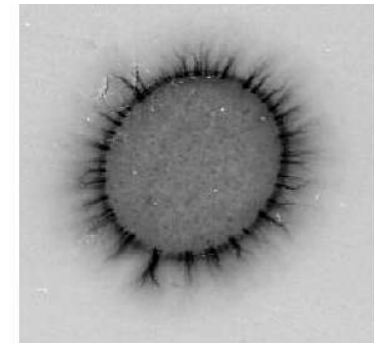

Заварка чаю

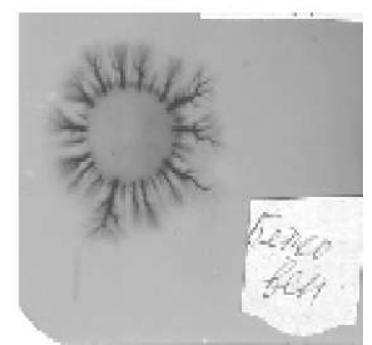

в/в після клас. музики

Puc. 1. Приклади різного малюнку стримерів корони випромінювання води.

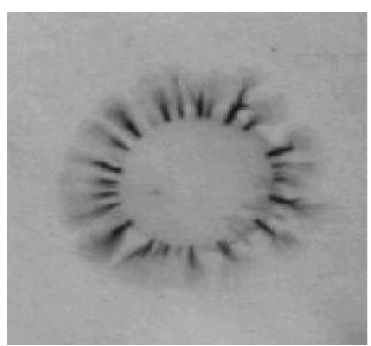

Дистильована вода

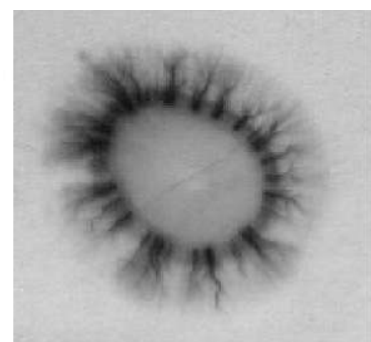

Природна вода

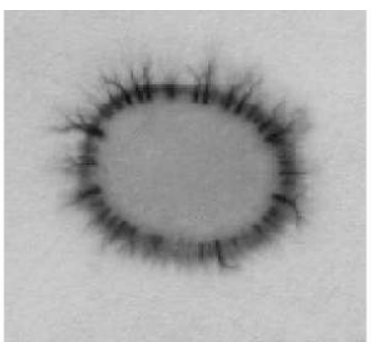

Водопровідна вода

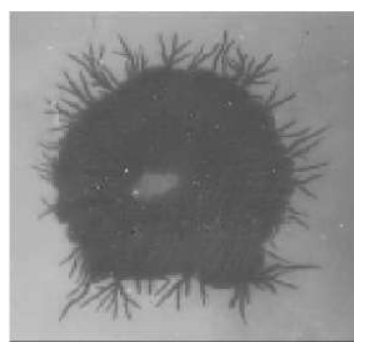

В/в після музики в стилі «Важкий рок»

Puc. 2. Кірліанофотографії води з різними дефектами стримерів в короні випромінювання. 
родних білків переважно входять лівообертальні амінокислоти (L-форма). Тобто тільки вони можуть брати участь у синтезі цих білків в клітинах, на відміну від правообертальних. Вода синтезу більш зв'язана і на кірліанограмі має меншу інтенсивність затемнення плівки (рис. 3).

Більш інтенсивне світіння у правообертального ізомеру віддзеркалює більшість вільних зв'язків в його структурі, порівняно з лівообертальним ізомером, i обумовлює їх якісні розбіжності. Наведені особливості інтенсивності кірліан-зображення ізомерів віддзеркалюють їх біологічні властивості.

Водночас встановлено, що D-амінокислоти також зустрічаються в природі, хоч рідше, ніж амінокислоти L-ряду, в основному - у світі низьких організмів. Вони присутні, наприклад в пептидних антибіотиках, в оболонці деяких бактерій. Термофільні мікроорганізми термальних вод використовують високі концентрації D-аланіну, як осморегулятора. Для отримання первинної структури білка з природною функціональністью з D-амінокислот досить і десяти їх [8].

Якщо урахувати, що у найпростіших одноклітинних істотах осмос є механізмом обміну речовин, а джерело енергії має анаеробний характер, то вища інтенсивність світіння стримерів буде зв'язана з меншим вмістом в ній кисню, і навпаки.

В. Л. Воєйков [2] підкреслює, що природна вода має цілющі властивості завдяки своєрідній структур- но-енергетичній організації, яка здатна до окислювання. Активні форми кисню (АФК) в присутності молекул води утворюють кванти енергії для активації нових порцій кисню в організмі для забезпечення високої швидкості біохімічних процесів. Динамічний стан такої води дозволяє при попаданні в організм перетворюватись як в ту, що потрібна для процесів гідролізу, так і в ту, що необхідна для процесів синтезу.

Як приклад не зруйнованої природної води наводимо кірліанограми води з території монастирів, порівняно $з$ водопровідною і стічною (рис. 4).

У короні випромінювання природної намоленої води, окрім правильної структури стримерів з достатньою їх довжиною і інтенсивністю випромінювання, привертають увагу однорідність та дрібна зернистість 3 малим затемненням плівки в зоні ії контакту з краплею, на відміну від водопровідної і ще більше стічної води. Досліджувалась природна вода Криму, намолена і динамічна, внаслідок чого безумовно збагачена киснем.

Звідси, насичення води активними формами кисню можна оцінювати за зображенням внутрішнього кола їі кірліанівського випромінювання.

При дослідженні ультрадисперсних утворювань на розпиленій мерзлій воді природних джерел в горах Полярного Уралу показано, що при замерзанні у воді утворюється особливий клас структур, які автори назвали «аквастигми». За результатами досліджень,
1 імпульс

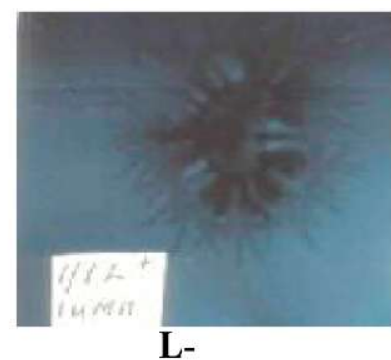

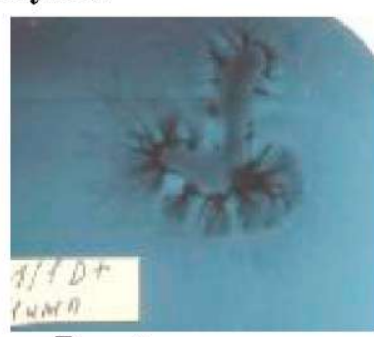

D-лейцин

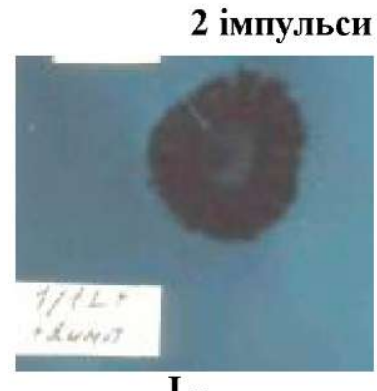

L-

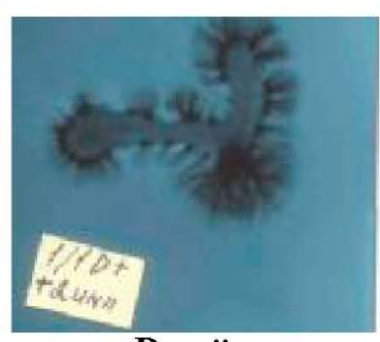

D-лейцин

Puc. 3. Кірліанофотографії водних розчинів 1: 1 право- і лівообертального ізомерів амінокислоти L- та Dлейцину на 1 і 2 імпульси.

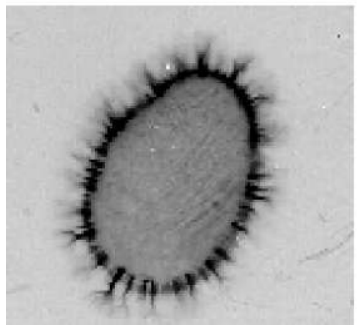

Стічна вода

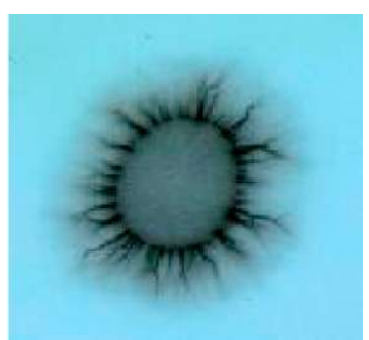

Водопровідна
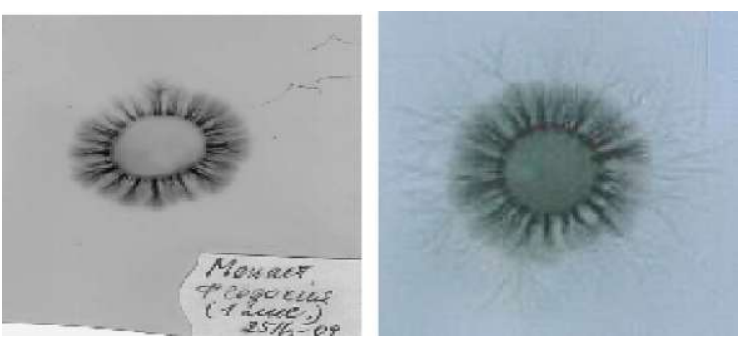

Вода $з$ Топловського монастиря

Puc. 4. Кірліанограми зразків води з території монастирів, порівняно з водопровідною і стічною. 
у Хрещенській і «святій» воді «автостигми» утворюються спонтанно. Зроблена спроба знайти взаємозв'язок між когерентним галактичним радіовипромінюванням такої води, випромінюванням тім'яної зони головного мозку людини і можливим випромінюванням знайдених структур, з відповідною їм всім радіохвилі 1,5 см [3]. Як відомо, переліченим водам притаманні цілющі властивості.

В літературі є дані про те, що для зміни структури води не обов'язковим є розрив зв'язків між атомами водню. Структурні зміни визначаються також мірою згинання водневих зв'язків (зміною кута між лінією, яка з'єднує центри найближчих молекул води, і напрямком зв'язку О-Н однієї з цих молекул). Енергія, яка необхідна для згинання водневих зв'язків, непомірно менша за енергію їх розриву. Таким чином, зміни структури води можливі при потребах енергії, набагато меншої енергії водневих зв'язків [13]. В цьому разі вода виконує більш інформаційну функцію, ніж енергетичну..

Такий механізм взаємодії відбувається на більш високому квантовому рівні, ніж хімічні реакції, і в ньому головна роль активації електронів буде віддана активному кисню. Така вода буде виконувати синтетичну функцію, i більше буде клітинною, охороняючи інформацію генотипу [2]. Вона стабільно структурована, має менше вільних зв'язків. Тобто буде менш збуцжгною, з меншою інтенсивністю засвічення плівки, що ми спостерігали у природній воді монастирів.
Кірліан-зображення водопровідної води і води з озеpa, які були взяті в день Успіння Пресвятої Богородиці, поряд із змінами в параметрах в'язкості, нагадували ознаки монастирської води (рис. 5).

Крім того, у «святій» воді 3 монастирів в короні світіння краплі візуалізуються світлі гомогенні краплини. В цьому разі мікроструктури води захоплюють енергію. У контрольній водопровідній воді візуа лізуються великі темні краплини - структури води реагують $з$ реактивом плівки з утворенням і викидом енергії фотонів світла. У природній воді спостерігаємо обидва види краплин, з більшістю світлих (рис. 6).

Наявність на кірлінограмі води двох видів крапок на внутрішньому крузі корони світіння віддзеркалює наявність в неї двох різних структур, з різними властивостями - дисиметрію. Як відомо, вона характерна для живого організму.

На наш погляд, наведені дані необхідно порівняти 3 ознаками когерентної води. Явище когерентності сьогодні розповсюджується для опису фізичного стану речовин, які об'єднані загальною властивістю упорядкованістю і узгодженою поведінкою великої кількості елементів речовини. Такий стан матерії назвали п'ятим станом речовини [6]. Авторами отримана когерентна R- i L- вода, яка, порівняно з контролем, мала деякі особливості. Зокрема, зниження диференційної напруги, аналогічно властивостям негатроних систем. Цей ефект нагадує резонанси

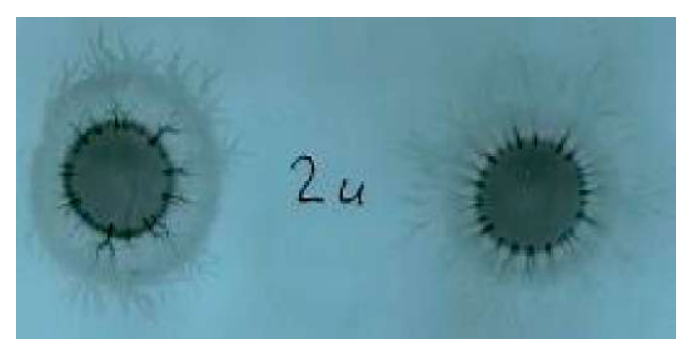

В/вода і вода з озера у звичайний день

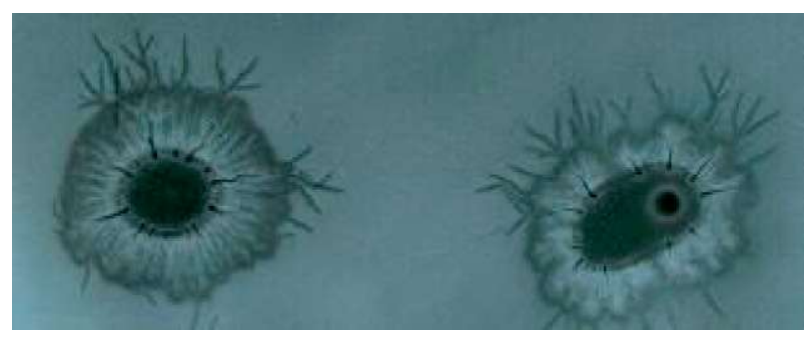

В день Успіння Пресв.Богородиці

Puc. 5. Кірліанографія водопровідної води і води з озера в різні дні дослідження

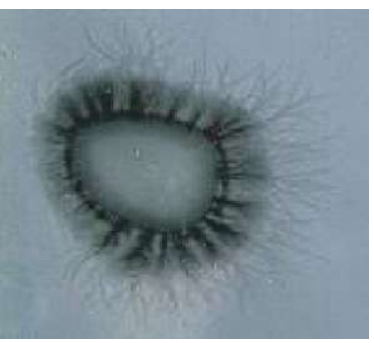

Оптіна Пустинь

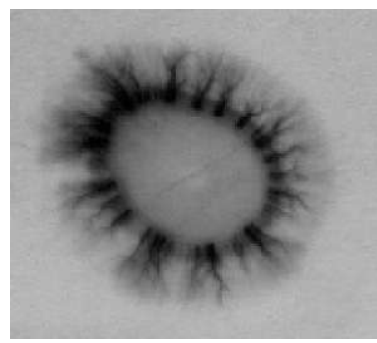

Джерело «Царичанка»

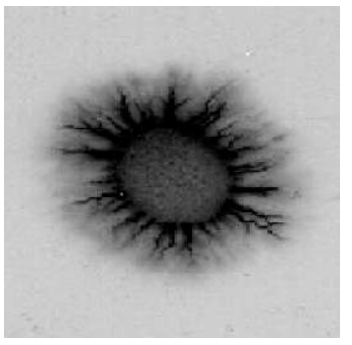

Водопровідна вода

Puc. 6. Кірліанфотографії зразків води з території монастирів, порівняно з водопровідною і природною. 
Шумана і альфа-ритми мозку людини. Для когерентної води спостерігали зростання електроємності, що також аналогічно властивостям негатроних систем. При цьому L - поляризована структура була більш упорядкованою ніж R-структура.

Таким чином, світлі крапки на плівці в місцях контакту краплі віддзеркалюють негатронні структури води, які «зкачують» іззовні енергію, тобто є ознакою ступеня когеренізації води. Темні краплини віддзеркалюють фракцію некогерентної (незв'язаної води), вільні зв'язки якої вступають в хімічні реакції з реактивом плівки з витратою енергії.

Визначена різниця в кірліан-світінні води залежно від ії природних властивостей вірогідно співвідноситься з особливостями клітинної і міжклітинної води в живому організмі.

\section{Лтература}

1. Виктор Сэхляну Физика, химия и математика жизни / Сехлену В. - Бухарест: Научное издательство, 1965. - 518 с. 2. Воейков В. Л. www. drvolkov.ru>index.php/?section=96.

3. Зубков А. Ф. Межфазовые переходы в тонких пленках и ультрадиспресных образованиях воды / А. Ф. Зубков // Тезисы XV Международного Научного Конгресса «Наука. Информация. Сознание». - Санкт-Петербург, 2011 г. C. 17.

4. Кирлиан С. Д. Авт. свід. №106401, кл. GO3В 41/00, 1949.

5. Корпачев В. В. Фундаментальные основы гомеопатической фармакотерапии / В. В. Корпачев. - К. : Четверта хвиля, 2005. $-96 \mathrm{c}$.

6. Краснобрыжев В. Г Свойства когерентной воды / В. Г. Краснобрыжев, М. В. Курик // Квантовая магия. 2010. - № 2. - С. 168.

7. Курик М. В. Кірліанографія біоенерго-інформаційного поля природної води / М. В. Курик, В. М. Лапицький,
Висновки. 1. Отримані особливості кірліансвітіння води на рентгенівській плівці віддзеркалюють іiі структурну природу.

2. За визначеними ознаками води при використанні методу класичної кірліанографії можна оцінювати їі упорядкованість і енергетичні властивості.

3. Класична кірліанографія може бути експресметодом визначення якості біоенергетики води і ï цілющих властивостей.

Перспективні напрямки розвитку теми. Подальші дослідження кірліанографії води доцільні і можуть бути початком визначення кірліанографічних ознак біологічної активності води, а також використовуватись для індивідуального підбору води з оздоровлюючою дією з урахуванням біоенергетики людини. Відкриваються можливості поглибленого вивчення структурно-енергетичних особливостей води в організмі здорової людини і при різних хворобах.

Л. А. Пісоцька // Медична та біологічна інформатика і кібернетика з міжнар. участю: зб. праць 20-23 квітня, 2011 р. Київ. - С. 74.

8. Леенсон И. А. Левое или правое? / И. А. Леенсон // Химия и жизнь. - № 5. - 2009. - С. 44 - 48.

9. Некрасов В. А. Биологическое поле, 2005 г. / www.antipole.ru/art/04; http://www.antipole.ru/art/01/

10. Стефанюк Б. М. Особливості води як молекулярно-асамблевої наноструктури / Б. М. Стефанюк // Світ фізики. 2011. - № 2 (54). - С. 12 - 19.

11. Спосіб оцінки енергоінформаційного стану рідиннофазного об'єкта і пристрій для його здійснення / Л. А. Пісоцька, В. М. Лапицький, К. І. Боцман, С. В. Геращенко // Патент України на корисну модель № 22212 від 25 квітня 2007 p.

12. wwweurolab.ua $>$ Гиды по здоровью $>565 / 43450$

13. www.nisleda.net. 